\title{
Lung cancer among iron ore miners in east Slovakia: a case-control study
}

\author{
Ján Icsó, Matilda Szöllösová, Tom Sorahan
}

The biological effects of ionising radiation (BEIR IV) report included a summary of risks of lung cancer in cohorts of miners exposed to radon daughters, ${ }^{1}$ and concluded that "without exception, these studies indicate an excess probability of death due to lung cancer ..." Iron ore mines have been in operation at Roznava and Nizna Slana in east Slovakia throughout this century. The mines, which are $10 \mathrm{~km}$ apart, are major employers in the area. Data on radiation exposures and dust concentrations are available for the period 1980-89. Local authorities found average levels of $\alpha$ radiation from radon and its daughters to be $0.13 \mathrm{WL}$ (working levels) in the Roznava mine and 0.091 WL in the Nizna Slana mine. Average concentrations of total dust in the two mines are similar (Roznava 2.6 mg. $\mathrm{m}^{-3}$, Ninza Slana $2.4 \mathrm{mg} \cdot \mathrm{m}^{3}$ ). During drilling operations, dust concentrations are about $15 \mathrm{mg} \cdot \mathrm{m}^{-3}$. Principal components of ores from the two mines are similar (oxides of iron, manganese, magnesium, calcium, phosphorus, and arsenic together with silica, sulphur, and carbon). Diesel machinery was introduced into the Nizna Slana mine in 1973; Roznava still uses electrically powered machinery.

Evidence of occupational lung cancers arising from employment in these mines has been reported before..$^{3} \mathrm{~A}$ case-control study has now been carried out to quantify the likely risks associated with employment in each mine.

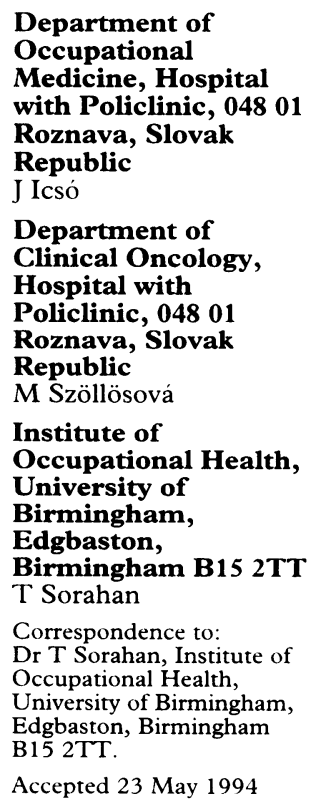

\section{Material and methods}

Cases comprised all new cases of lung cancer diagnosed in the period 1980-1989 at the $\star \star \star \mathrm{P}<0.001$

†Ever or never employed as an underground iron ore miner.
Department of Clinical Oncology, Roznava, among men resident in the Roznava $(\mathrm{n}=140$ ) or Nizna Slana areas $(n=60)$. Cases were classified as either ever or never employed as an underground iron ore miner on the basis of occupations recorded in hospital notes. All cases were registered with one of the five local general practitioners. Controls were selected from lists of patients registered with these five local general practitioners. Records for every tenth man in these lists were selected; 196 controls from the practice lists of the three general practitioner surgeries in the Roznava area and 228 controls from the two general practitioner surgeries in the Nizna Slana area. Controls were classified as ever or never employed as underground iron ore miners on the basis of occupational data held by the general practitioners and on information received from them.

An estimate of the relative risk of lung cancer associated with iron ore mining was provided by a Mantel-Haenszel analysis after controlling for age (year of birth) ${ }^{4}$

\section{Results}

The table shows the data by area, case or control state, and occupation. Increased relative risks are associated with iron ore mining in both areas (Roznava: RR $2 \cdot 81,95 \%$ confidence interval $(95 \%$ CI) $1 \cdot 69-5 \cdot 21$; Nizna Slana: RR $4 \cdot 01,95 \%$ CI 2.07-9.06). The proportion of cigarette smokers among miners with lung cancer was $77 \%$ for the Roznava series and $60 \%$ for the Nizna Slana series. Duration of mining employment was available for 42 of the Roznava cases and 14 of the Nizna Slana cases. Mean durations of mining employment for these two groups of cases were 25.5 years and 23.4 years respectively,

Relative risk of incidence of lung cancer among iron ore miners ${ }^{\dagger}$ in two districts of east Slovakia

\begin{tabular}{|c|c|c|c|c|c|c|c|c|}
\hline \multirow[b]{3}{*}{ Year of birth } & \multicolumn{4}{|l|}{ Roznava } & \multicolumn{4}{|c|}{ Nizna Slana } \\
\hline & \multicolumn{2}{|l|}{ Cases } & \multicolumn{2}{|c|}{ Controls } & \multicolumn{2}{|l|}{ Cases } & \multicolumn{2}{|l|}{ Controls } \\
\hline & Miner & $\begin{array}{l}\text { Non- } \\
\text { mener }\end{array}$ & Miner & $\begin{array}{l}\text { Non- } \\
\text { miner }\end{array}$ & Miner & $\begin{array}{l}\text { Non- } \\
\text { miner }\end{array}$ & Miner & $\begin{array}{l}\text { Non- } \\
\text { miner }\end{array}$ \\
\hline$<1909$ & 3 & 13 & 5 & 6 & 6 & 4 & 1 & 5 \\
\hline $1910-19$ & 29 & 10 & 8 & 18 & 8 & 11 & 5 & 18 \\
\hline $1920-29$ & 28 & 29 & 11 & 30 & 9 & 7 & 9 & 45 \\
\hline $1930-39$ & 15 & 7 & 13 & 26 & 6 & 6 & 19 & 36 \\
\hline $1940-49$ & 1 & 3 & 2 & 26 & 3 & 0 & 5 & 30 \\
\hline $1950-59$ & 0 & 1 & 3 & 27 & 0 & 0 & 0 & 30 \\
\hline $1960-69$ & 0 & 1 & 1 & 21 & 0 & 0 & 1 & 24 \\
\hline Total & 76 & 64 & 43 & 153 & 32 & 28 & 39 & 189 \\
\hline Relative risk $(95 \% \mathrm{CI})$ & $2 \cdot 81^{\star \star \star}$ & \multicolumn{3}{|c|}{$(1 \cdot 69-5 \cdot 21)$} & & $4 \cdot 01^{\star \star \star}$ & \multicolumn{2}{|c|}{$(2 \cdot 07-9 \cdot 06)$} \\
\hline
\end{tabular}


providing estimated cumulative radiation doses of 37.5 WLM and 24.0 WLM. Corresponding data for miners in the two control series are not available.

\section{Discussion}

The case series are likely to be complete because it is obligatory for cases of cancer to be registered at the local clinic. It is unusual for ex-employees to leave the local area, and one feature of the centrally run economy that existed until recently was a lack of mobility in the workforce. The miner or non-miner classification will, therefore, approximate to a life long classification.

The study is limited by the absence of data on smoking for cases and controls, the use of different sources of information for the occupational classification, and the absence of cumulative exposure estimates. It seems clear, however, that excess risk of lung cancer is present. There are a number of carcinogens or potential carcinogens present in the mines and it is not possible, from these data, to attribute risks to the various exposures present. Working conditions may have to be improved in several ways before it will be possible to state with any confidence that occupational lung cancers will cease to occur.

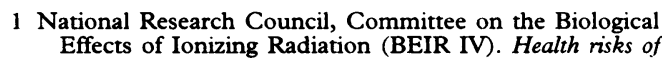
radon and other internally deposited alpha-emitters. Washington, DC: National Academy Press, 1988.

2 Pekárek V. Radon a jeho dcerinné produkty v ovzdusí rudnych dolu severoceského kraje a vyskyt profes. rakoviny plic u exponovanych hraje a vyskyt profes. rakoviny plic u

3 Icsó J, Szöllösová $M$. Vyskyt plúcnej rakoviny u baníkov zelezorudnych bani. Pracov Lék 1984;36:294-8.

4 Mantel N, Haenszel W. Statistical aspects of the analysis of data from retrospective studies of disease. $\mathcal{F}$ Natl Cancer Inst 1959;22:719-48. 